\title{
The Effect of Metformin upon Spermatogenesis in Mice
}

\author{
Aalaa M. Ayyad ${ }^{1}$ and Mohamed A. El-Seehy ${ }^{1}$
}

\begin{abstract}
The effect of the drug Metformin has been studied, employing Mice genome (mus musculus $2 n=40$ ) . Three doses 250,500 and $1000 \mathrm{mg} / \mathrm{ml}$ in addition to the negative control were tested. The results obtained has now been reported for the first time; since a significant increases in sperms 10 fold-increases were obtained. It seems probable that such effect might be caused by enhancement of cell division.
\end{abstract}

Key words: Metformin, sperm, mice genome.

\section{INTRODUCTION}

Spermatogenesis is the process by which haploid spermatozoa develop from germ cells in the seminiferous tubules of the testis. This process starts with the mitotic division of the stem cells located close to the basement membrane of the tubules. These cells are called spermatogonial stem cells. The mitotic division of these produces two types of cells. Type A cells replenish the stem cells, and type B cells differentiate into spermatocytes. The primary spermatocyte divides mitotically (Meiosis I) into two secondary spermatocytes; each secondary spermatocyte divides into two equal haploid spermatids by Meiosis II. The spermatids are transformed into spermatozoa (sperm) by the process called Spermatogenesis. These develop into mature spermatozoa, also known as sperm cells ( Sharma et al., 2018). Thus, the primary spermatocyte gives rise to two cells, the secondary spermatocytes, and the two secondary spermatocytes by their subdivision produce four spermatozoa.

Spermatozoa are the mature male gametes in many sexually reproducing organisms. Thus, spermatogenesis is the male version of gametogenesis, of which the female equivalent is oogenesis. In mammals it occurs in the seminiferous tubules of the male testes in a stepwise fashion. Spermatogenesis is highly dependent upon optimal conditions for the process to occur correctly, and is essential for sexual reproduction. DNA methylation and histone modification have been implicated in the regulation of this process (Song et al.,2011) It starts at puberty and usually continues uninterrupted until death, although a slight decrease can be discerned in the quantity of produced sperm with increase in age.

Metformin is primarily used for the treatment of type 2 diabetes mellitus, particularly in obese patients.
Metformin has been shown to reduce diabetes mortality and complications by thirty percent compared to insulin, glibenclamide and chlorpropamide. ( Rafieian-Kopaei and Baradaran 2013).

\section{MATERIALS AND METHODS}

The experimental work of this study was carried out at Laboratory of Genetic Toxicology, Faculty of Agriculture, Alexandria University, Department of Genetics, The present investigation was planned to: Investigate the effect of metformin upon germinal line in mice. The drug was locally purchased and used in three doses 250,500 and $1000 \mathrm{mg}$ per kg body weight.

Mice (Mus musculus 2n=40) were employed and each mouse had taken the proper dose once a day for a 30 days. Cell collection was carried out according to (Pary and Pary 1984).

Geimsa stain was used and cells were microscopically investigated, counted and photographed where needed.

Drug used:

Metformin (dimethylbiguanide) features as a current first-line pharmacological treatment for type 2 diabetes (T2D) in almost all guidelines and recommendations worldwide. It has been known that the antihyperglycemic effect of metformin is mainly due to the inhibition of hepatic glucose output, and therefore, the liver is presumably the primary site of metformin function.<smiles>CN(C)C(=N)NC(=N)N</smiles>

Figure 1.The chemical component of metformin Formula of metformin $\quad \mathrm{C}_{4} \mathrm{H}_{11} \mathrm{~N}_{5}$
Molar mass
$129.16364 \mathrm{~g} / \mathrm{mol}$

However, in this issue of Diabetes Care, Fineman and colleagues (Buse et al., 2016) demonstrated surprising results from their clinical trials that suggest the primary effect of metformin resides in the human gut.

Metformin, marketed under the trade name Glucophage among others, is the first-line medication

${ }^{1}$ Department of genetics, faculty of agriculture,Alexandria unniveristy. Received May 20, 2018, Accepted June 10, 2018 
for the treatment of type 2 diabetes ( Maruthur et al., 2016) particularly in people who are overweight.

\section{Experimental animal model:}

A total of 60 male albino mice, Mus musculus, (25$30 \mathrm{~g}$ ) were obtained from the Medical Research Institute Alexandria University. Animals were kept in plastic cages (ten animals per cage) covered with metallic grids in a room maintained at proper environmental conditions of temperature $25^{\circ} \mathrm{C}$ and humidity $50 \%$ with a 12-hours light-dark cycle. The animals were acclimatized for 4 weeks before the start of the experiment and they were given free access food and water.

\section{Glucophage experiment design:}

Sixty male albino mice were divided randomly into four groups. The duration for all experimental groups was 30 days (Xie et al., 2000).

-Group 1: normal control group of fifteen mice. These mice did not receive any treatment during the experiment stages.

-Group 2: Glucophage commercial formula for Metformin, was treated for this group and fifteen mice had received one tablet of Glocophage dissolved in $100 \mathrm{ml}$, double distilled water, respectively. They had received $250 \mu 1$ daily in oral dose.

-Group 3: Glucophage commercial formula for Metformin, was treated for this group and fifteen mice had received one tablet of Glocophage dissolved in $100 \mathrm{ml}$, double distilled water, respectively. They had received $500 \mu \mathrm{l}$ daily in oral dose.

-Group 4: Glucophage commercial formula for Metformin, was treated for this group and fifteen mice had received one tablet of Glocophage dissolved in $100 \mathrm{ml}$, double distilled water, respectively. They had received $1000 \mu \mathrm{l}$ daily in oral dose.

\section{Analysis of mice primary spermatocytes}

Fifteen male mice were used for each dose. Doses had orally given one time daily for a 30 days. Ten days after the last dose the animals were killed by cervical dislocation. The used procedure follows basically the description given by Oud et al., (1979); Adler (1984); Seehy and Osman (1989) and Seehy M. (2007).

\section{Tissue sampling:}

The testes were removed by making an incision into the scrotum and fat tissue was cleaned. The tunica were removed, transferred the tubules to a small Petri dish containing apiece of fly mesh and 3-4 ml of $2.2 \%$ trisodium citrate. The tubules were cut up with forceps several times, and then they were mashed on the fly mesh with flat-top forceps. The fluid containing the cells was transferred to $12 \mathrm{X} 100 \mathrm{~mm}$ round-bottom centrifuge tubes, centrifuged at $1000 \mathrm{rpm}$ for $5 \mathrm{~min}$. supernatant was completely discarded. The hypotonic solution (1\% trisodoum citrate) was slowly added and centrifuged, after 15-20 $\mathrm{min}$, and then the cells were fixed in (methanol: glacial acetic acid, 3:1). The fixative was changed twice after $10 \mathrm{~min}$ for each by centrifugation between changes.

\section{Staining}

The slides were stained for at least 10 min using 10 $\%$ Giemsa (PH6.8), washed air-dried and examined microscopically.

\section{RERSULTS AND DISCUSSION}

As shown table 1 it was found that the total number of cells was found to be 2500, 5000, 12000 and 1000 after treatment with 250, 500 and 1000 doses and control,respectively.

The relative percent of cells to the control group $\%$ at the level of this study was $2.5 \%, 5 \%$ and $12 \%$.

It is clear that the drug metformin was proven to be capable in inducing significant increases in animal sperms, and accordingly in animal fertility.

Attia et al, (2009) reported metformin was neither genotoxic nor cytotoxic for the rats in all groups at all tested doses. Moreover, metformin significantly reduced the diabetes-induced genomic instability and cell proliferation changes in somatic and germinal cells in a dose-dependent manner $(2500,500,>100 \mathrm{mg} / \mathrm{kg})$. In addition, diabetes induced marked biochemical alterations characteristic of oxidative stress including, enhanced lipid peroxidation and reduction in the reduced glutathione level. Treatment with metformin ameliorated these biochemical markers. In conclusion, metformin is a non-genotoxic or cytotoxic compound and may protect from genomic instability induced by hyperglycemia. Apart from its well-known anti-diabetic effect, the antigenotoxic effect of metformin could be possibly ascribed to its radical scavenger effect that modulated the genomic instability responses and cell proliferation changes induced by hyperglycemia.

Metformin, an old antidiabetes drug, may inhibit prostate intraepithelial neoplasia transforming to cancer lesion via reducing c-MYC, an 'old' overexpressed oncogene. This study explores chemopreventive efficacy of metformin in prostate cancer and its link to cMYCin vitro and in vivo.Akinyeke et al., (2013). 

Table 1. shows the effect of different doses of metformin upon number of sperms after treatment for 30 days Dose $\mathrm{mg} / \mathrm{ml}$ Number of cells Percent; relative to negative

\begin{tabular}{ccc} 
& control \% \\
\hline 250 & 2500 & 2.5 \\
500 & 5000 & 5 \\
1000 & 12000 & 12 \\
$\mathrm{NC}$ & 1000 & 1 \\
\hline
\end{tabular}

*NC : Negative Control.

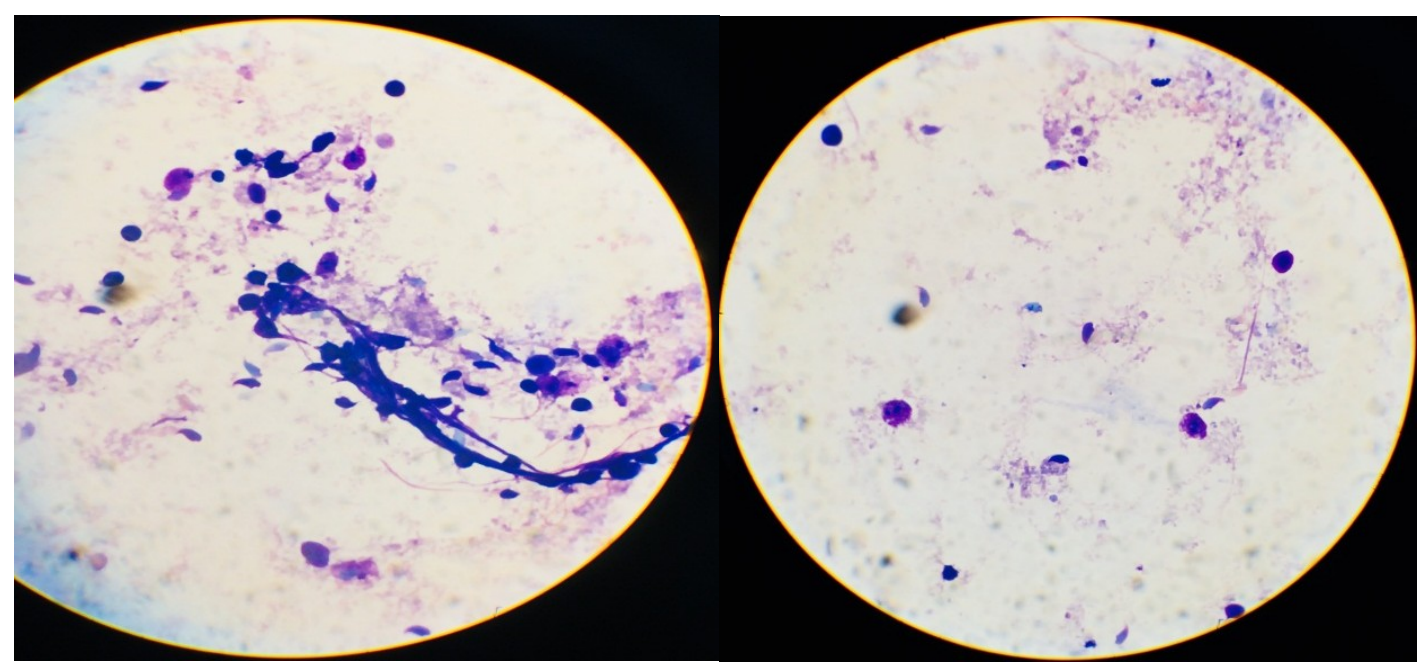

(a)

(b)

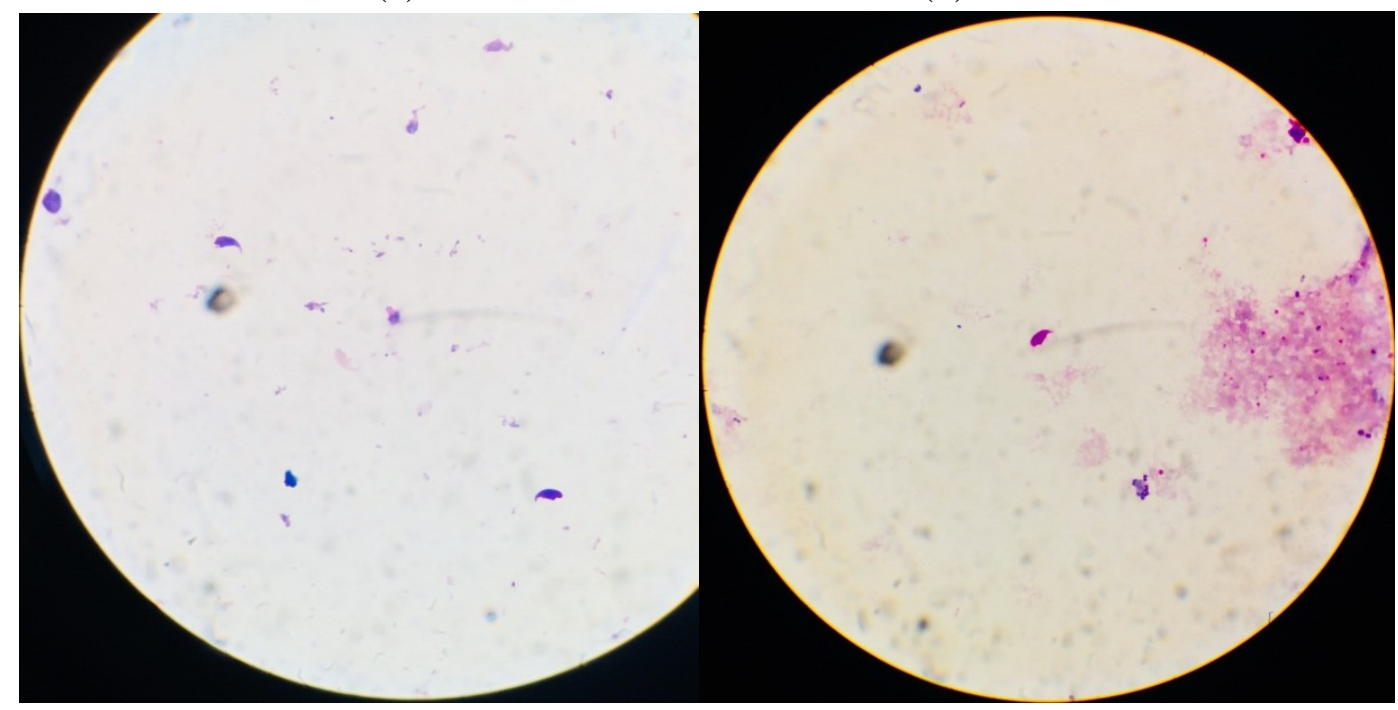

(c)

(d)

Fig.2.Photomicrograph showing. (a) High increases in number of sperm due to the $1000 \mathrm{mg} / \mathrm{ml} \mathrm{dose.} \mathrm{(b)} \mathrm{The}$ effect of dose $500 \mathrm{mg} / \mathrm{ml}$. (c) The effect of $250 \mathrm{mg} / \mathrm{ml}$ dose. (d) The negative control

Therefore, metformin may be a potent candidate for chemoprevention of liver tumorigenesis in patients with obesity or diabetes.(Ohno et al.,2015)
The concolusion came from the present investigation is the following:

The effect of metformin has now been observed for the first time by Aalaa Ayyad and Mohamed El-Seehy 
that the drug metformin is capable to increase mammalian fertility One can conclude that this effect is caused by its capability to enhance cellular division.

\section{REFERENCES}

Abdelrasoul, A.M.2018. Modulation of abamectin and indoxacarb -induced toxicity on male albino rats by Moringa oleifera. Alex. Sci. Exch. J.39:P 232-243.

Adler, I.D .1984. Cytogenetic test in mammals, In; mutagenecity testing, a practical approach (Venitt, S. and parry, j.M. EDs.), IRL press, Oxford.

Akinyeke, T., S.Matsumura, X. Wang, Y. Wu , E.D. Schalfer , A. Saxena, W. Yan, S.K. Logan and X. Li. 2013. Metformin targets c-MYC oncogene to prevent prostate cancer. Carcinogenesis. 34(12):2823-32.

Asmaa A. K. .2017. Effect of lannat pesticide on growth performance and chromosomal aberrations in nile tilapia (Oreochromis Niloticus L.). Alex. Sci. Exch. J.38 :770778.

Attia, S.M., G.K. Helal and A.A. Alhaider . 2009. Assessment of genomic instability in normal and diabetic rats treated with metformin. ChemBiol Interact. 180(2):296-304.

Buse, J.B., R.A DeFronzo, J. Rosenstock. 2016.The primary glucose-lowering effect of metformin resides in the gut, not the circulation: results from short-term pharmacokinetic and 12-week dose-ranging studies. Diabetes Care .39:198-205.

Maruthur, N.M., E. Tseng, S. Hutfless, L.M. Wilson, C. Suarez-Cuervo, Z. Berger, Y. Chu, E. Iyoha, J.B. Segal and S. Bolen. 2016. Diabetes medications as monotherapy or metformin-based combination therapy for type 2 diabetes: A Systematic Review and Meta-analysis. Annals of Internal Medicine. 164 (11): 740-51.
Oud, J. L. J. H. de Jong, and D. G. de Rooize.1979. A sequential analysis of meiosis in the male mouse using a restricted spermatocyte population obtained by ahy-droxy area /triaziquone treatment. Chromosoma,71:237-248.

Parry E.M, and Z.M. Parry.1984. the assay of genotoxicity of chemical using the budding Yeast usaccuromycescervisiae, in mutagenecity testing, apratical approach (EDs-S. Venitt and J.M. Parry) IRL Press, Oxford, Washington.

Rafieian-Kopaei, M, A.Baradaran.2013. Combination of metformin with other antioxidants may increase its renoprotective efficacy. J Ren Inj Prev.2:35-6.

Seehy, M. .2007. Micro and macro DNA damage induced by fast foods. PhD. Thesis Dept. Genetics. Alex. Univ.

Seehy, M.A., and M.A.Osman.1989. Evaluation of nystation gnotoxicity: II bone marrow chromosomes;micronucleus test; primry spermatocytes; and sister chromatid exchange. Bull. Alex.Fac.Medicine. XXV (6):1631-1636.

Sharma S, A. Hanukoglu and I. Hanukoglu .2018. Localization of epithelial sodium channel $(\mathrm{ENaC})$ and CFTR in the germinal epithelium of the testis, Sertoli cells, and spermatozoa. Journal of Molecular Histology. 49 (2): 195-208.

Song, Ning, J. Liu, S. An, T.Nishino, Y.Hishikawa, and T.Koji.2011. Immunohistochemical analysis of histone H3 modifications in germ cells during mouse spermatogenesis. Acta Histochemica et Cytochemica. 44 (4): 183-90.

Ohno,T., M. Shimizu,Y.Shirakami, A.Baba,T. Kochi, M. Kubota, H.Tsurumi,T.Tanaka,and H.Moriwaki 2015. Metformin suppresses diethylnitrosamine-induced liver tumorigenesis in obese and diabetic C57BL/KsJ+ lepr $^{d b} /+$ lepr $^{d b}$ mice.PLoS One. 10(4): e0124081.

\section{الملخص العربي}

$$
\begin{aligned}
& \text { تاثير عقار المتفورمين علي تكوين الحيوانات المنوية في الفئران المعملية } \\
& \text { الاء عياد و محمد الصيحي لوني } \\
& \text { وقد جاءت نتائج البحث حيث تم ملاحظة زبــادة عــدد }
\end{aligned}
$$

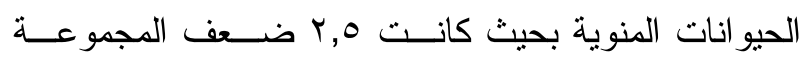

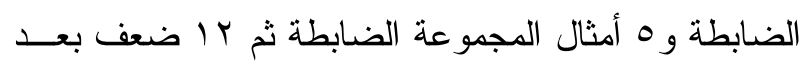

$$
\begin{aligned}
& \text { المعاملة بالجر عة الأعلى. }
\end{aligned}
$$

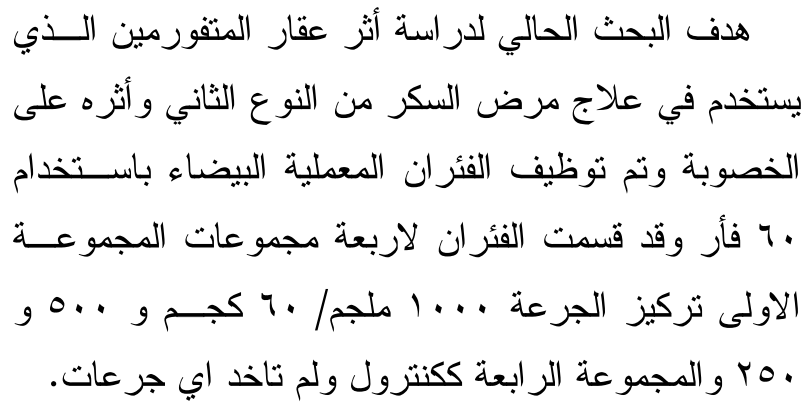

